\title{
Scar site metastasis of renal cell carcinoma diagnosed on-site cytology: a case report
}

\author{
Santosh Tummidi ${ }^{*} \mathbb{D}$, Pragati Sathe, Prachi Gholap, Manoj Patil and Kanchan Kothari
}

\begin{abstract}
Background: Renal cell carcinomas (RCCs) have a propensity for widespread metastases and a wide range of survival rates. They can spread into adjacent organs by direct extension and can invade local or distant sites by lymphatic, hematogenous or lympho-hematogeneous pathways. Scar site metastasis is very rare.

Case presentation: We report a rare case of scar site RCC metastasis in a patient who underwent left radical nephrectomy 10 months ago.

Conclusion: FNAC is a simple and easy technique that can help in the definitive diagnosis of subcutaneous lesions. A correct early stage diagnosis of metastatic RCC can considerably improve the survival rates.
\end{abstract}

Keywords: Renal cell carcinoma, Fine needle cytology, Scar recurrence, Toluidine blue, Nephrectomy

\section{Background}

Renal cell carcinoma (RCC) is one of the most aggressive genitourinary cancers with unpredictable and diverse behavior [1]. There has been an increase in the incidence of RCCs over the last 2 decades [2]. About $30-50 \%$ of patients were found to have metastases by the time of diagnosis. Bone, lymph nodes, lungs, and brain constitute expected 'homing' sites, whereas metastasis may turn up at unusual locations too [3].

Scar site metastasis after nephrectomy is very rare with only a few cases reported in the literature [1]. Fine needle aspiration (FNA) is an excellent tool for early diagnosis of subcutaneous nodules which in presence of characteristic cytomorphology excludes the need for any invasive methods [4]. We report a case of scar site metastasis diagnosed on FNA.

\section{Case presentation}

A 68-year-old male, presented with complaints of swelling over the left lower abdominal wall for 1 month. The swelling was along the scar of radical nephrectomy that had been done 10 months ago for renal cell carcinoma. The primary tumor on histology was a conventional (clear cell) RCC with Fuhrman nuclear grade 2 and there

\footnotetext{
* Correspondence: born_vss@yahoo.co.in

Department of Pathology, Seth GSMC \& KEMH, Parel, Mumbai 400012, Maharashtra, India
}

(c) The Author(s). 2018 Open Access This article is distributed under the terms of the Creative Commons Attribution 4.0 International License (http://creativecommons.org/licenses/by/4.0/), which permits unrestricted use, distribution, and reproduction in any medium, provided you give appropriate credit to the original author(s) and the source, provide a link to the Creative Commons license, and indicate if changes were made. The Creative Commons Public Domain Dedication waiver (http://creativecommons.org/publicdomain/zero/1.0/) applies to the data made available in this article, unless otherwise stated. was involvement of renal capsule and gerota's fascia with extension up to the perinephric fat.

On examination, the patient had a well-defined, soft, non-tender, reddish non-pulsatile cystic swelling over the left lumbar region near the scar mark. Figure $1 \mathrm{He}$ had no inguinal lymphadenopathy. USG abdomen pelvis revealed two well-defined hypo-echoic to iso-echoic lesions in the lateral abdominal wall measuring $19 \times 16 \mathrm{~mm}$ and $18 \times 16 \mathrm{~mm}$ at scar site with no evidence of vascularity within the scar. Radiological impression was a keloid. FNA from the swelling was done and screened onsite for adequacy by toluidine blue stain. Routine Papanicolaou (PAP) and Giemsa stains were also performed.

Smears were hemorrhagic and showed epithelial cells in loose clusters and scattered singly. The tumor cells had a round to polygonal shape with eccentrically placed hyperchromatic nuclei and prominent nucleoli. Cytoplasm was abundant and granular, eosinophilic to vacuolated. The clusters showed delicate, fibrillary fibrovascular cores. A few bizarre cells were also seen. Figures. 2,3,4 With the above morphology that was characteristic of RCC and the history, a diagnosis of metastatic renal cell carcinoma to the scar site was given. Immunocytochemistry showed CD10 positivity in tumor cells. At last, follow up the patient had expired 6 months after FNA, he had taken no further treatment due to his poor socioeconomic condition. 


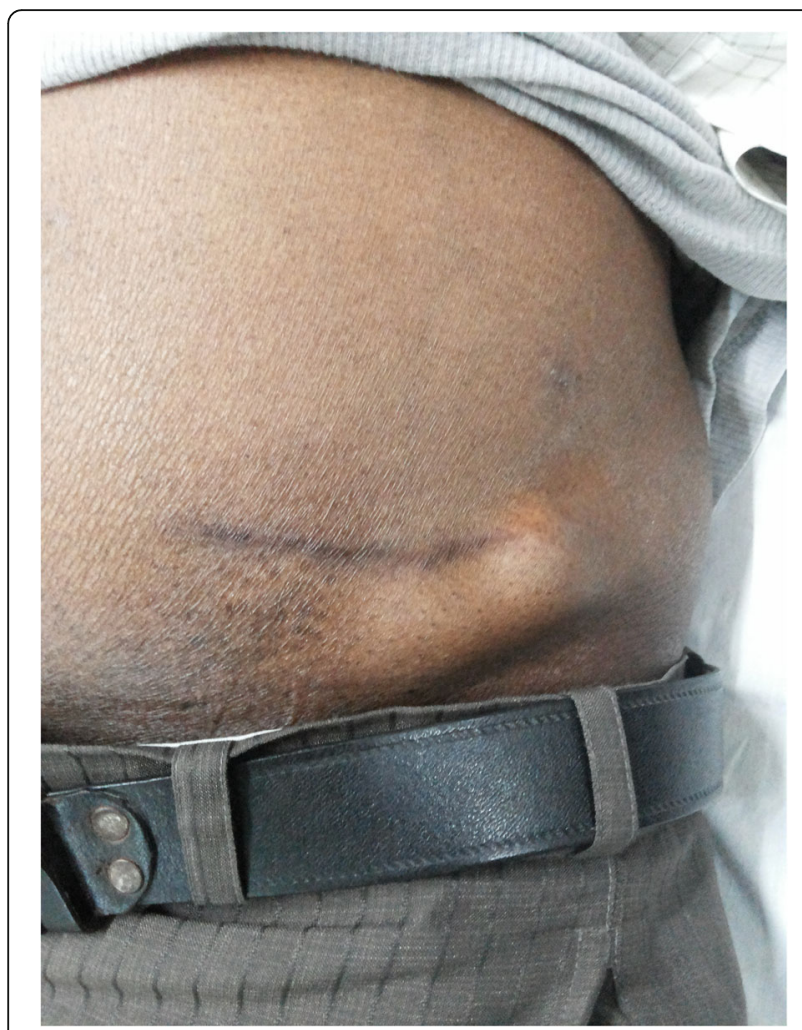

Fig. 1 Sub cutaneous swelling over the left iliac region near the previous scar site

\section{Discussion and conclusions}

RCCs are a heterogeneous group of tumors with 1/ 3rd of patients already having distant metastases at the time of diagnosis and in $1 / 4$ th of patient's metastasis occurs after radical nephrectomy. The tumors frequently metastasize to the lung (50-75\%), bone $(30-40 \%)$, liver (30-40\%), brain and thyroid (25\%) [1]. This event usually occurs after many years but could be the presenting feature of underlying cancer. Scar site metastasis following conventional radical nephrectomy is very rare. In recent years the numbers of laparoscopic nephrectomies have increased, raising the doubt regarding the oncologic safety of this approach, especially regarding local or port-site metastasis. However, randomized studies have not been able to show any significant difference in the incidence of scar-site metastases (0.9-1.8\%) following conventional open nephrectomies and port-site metastases following laparoscopic nephrectomies [5]. Pathogenesis of scar-site metastases from RCC is multifactorial. The reported gap for recurrence is 6 months to 5 years after initial diagnosis/nephrectomy [4, 6]. Major contributing factors include natural tumor behavior, local wound factors, and immunity. Following open nephrectomies, the most important factor for tumor cell dissemination has been improper techniques/manipulation [7]. Our patient underwent a conventional radical nephrectomy and there was no documentation of any tumor spillage during surgery.

The cytological differentials of scar site metastasis of RCC include histiocytic cells arranged singly or in groups

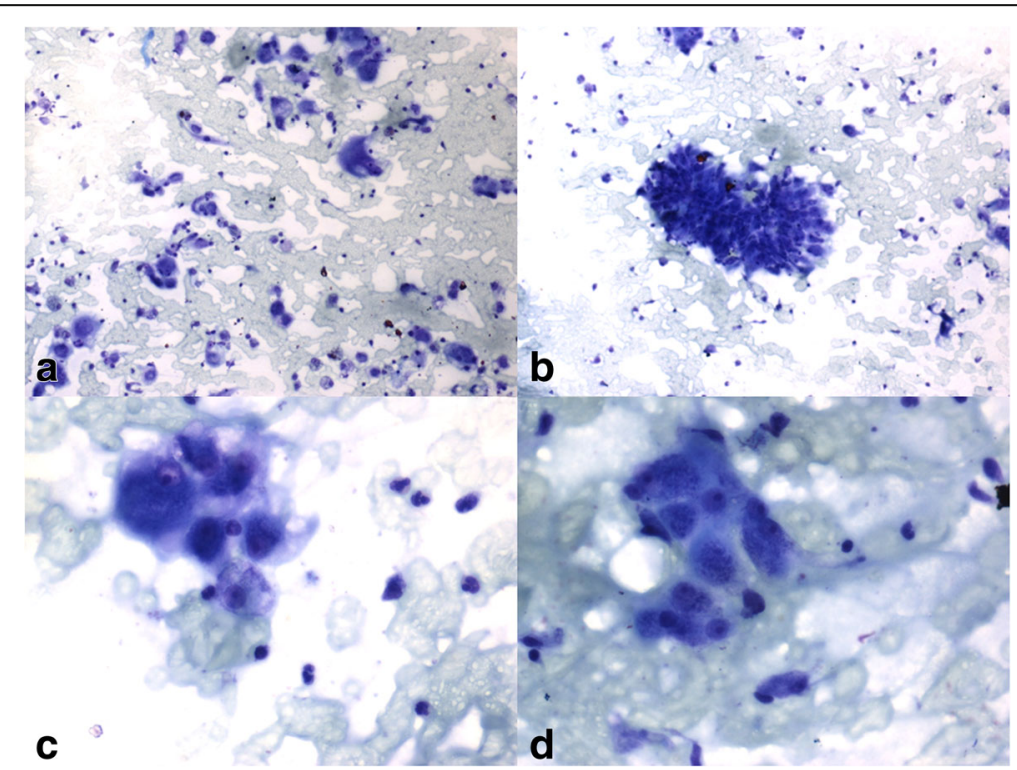

Fig. 2 a Smears were blood mixed with malignant epithelial cells scattered singly and in clusters (b). $\mathbf{c}$, d Tumor cells with round to polygonal shape, eccentrically placed hyperchromatic nuclei \& prominent nucleoli. Cytoplasm was abundant and granular eosinophilic $(T B, \times 10, \times 40)$ 


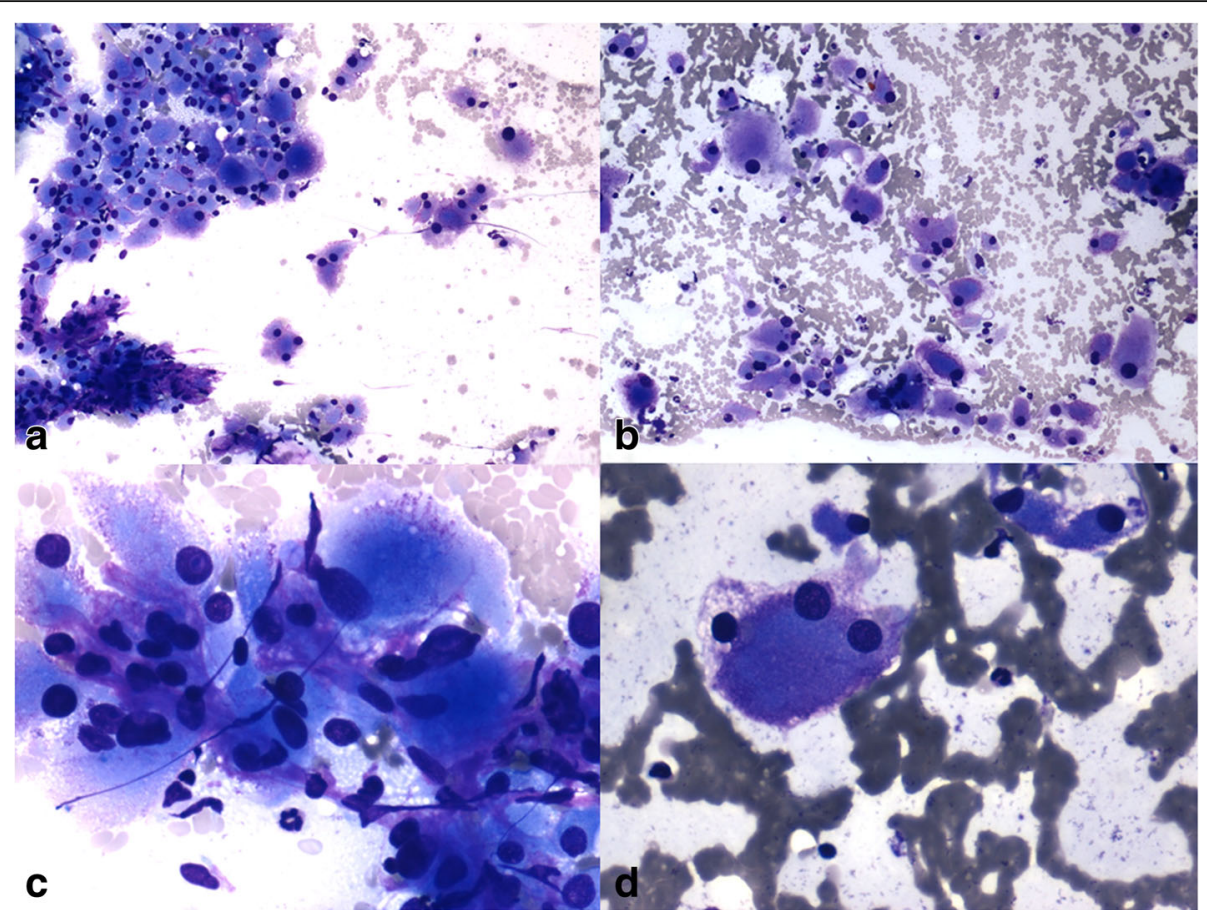

Fig. 3 a Cytosmears were blood mixed with malignant epithelial cells scattered singly and in clusters (b). c, d: Round to polygonal shaped tumor cells with eccentrically placed hyperchromatic nuclei \& prominent nucleoli. Cytoplasm was abundant and granular eosinophilic (Giemsa, × 10, × 40)

as the cells have abundant vacuolated cytoplasm with a low nuclear cytoplasmic ratio. Nucleoli may be prominent depending on the Fuhrman grade of the tumor. Careful attention to the nuclear morphology and the presence of delicate fibrillary vascular cores between tumor cells aids correct diagnosis. Other differentials include fibrohistiocytic

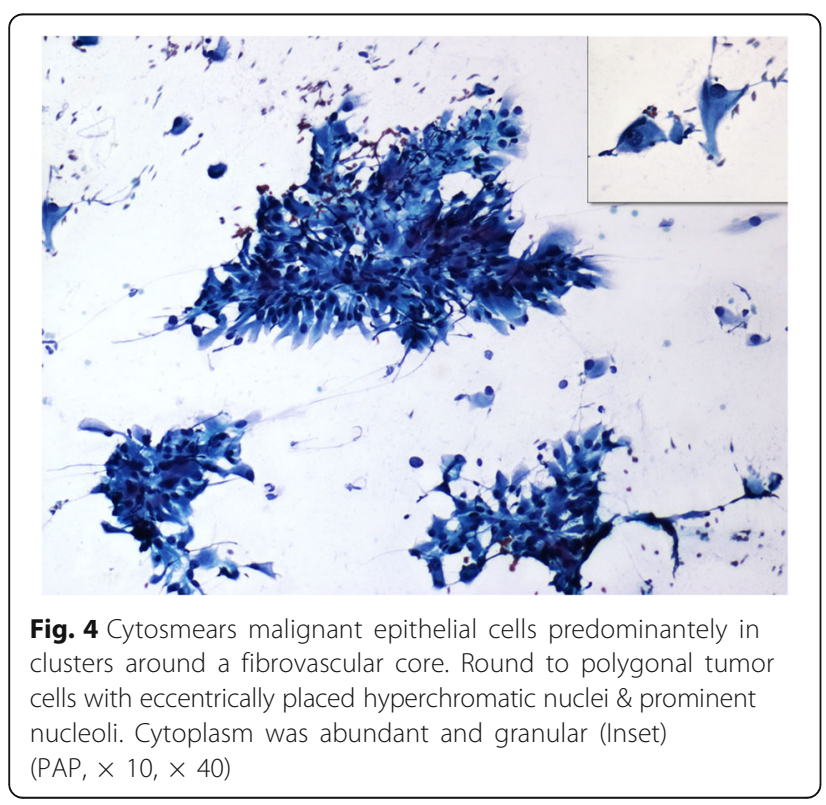

lesions of the skin and subcutaneous tissue (xanthomatous dermatofibroma, MFH, plexiform fibrohistiocytic tumor, xanthoma, and granular cell tumor) and various skin adnexal tumors (sebaceous hyperplasia, sebaceous adenoma and carcinoma, clear cell sarcoma, clear cell syringoma, clear cell hidradenoma and clear cell porocarcinoma) [8].

Immunochemistry can play an essential role in differentiation of the malignant cells in metastatic RCC at subcutaneous tissue from the other benign/malignant lesions of skin. Markers such as RCCma, CD10, EMA and PAX 8 suggest renal origin [6]. The other markers which are helpful include histiocytic markers (CD68 and lysozyme) in fibrohistiocytic lesions; CD34 and Factor XIIIA in dermatofibroma; keratin and EMA for sebaceous carcinoma; S100, HMB-45, and Melan-A for clear cell sarcoma $[4,6]$.

Management for local recurrence includes conservative treatment, surgery, radiotherapy or combination treatments [9]. Overall, the occurrence of subcutaneous metastases portends a poor outcome.

Subcutaneous scar site metastases from RCC are uncommon and typically imply a very poor prognosis and short survival. FNA can be a rapid and quick technique for detection of the metastatic lesion at superficial subcutaneous sites. Complete clinical history with immunocytochemistry if needed is useful for diagnosis. 


\section{Abbreviations}

CD: Cluster of differentiation; EMA: Epithelial membrane antigen; FNA: Fine needle aspiration; HMB: Human melan black; PAP: Papanicolaou; PAX: Paired box gene; RCC: Renal cell carcinoma; SMA: Smooth muscle actin

\section{Acknowledgements}

Not applicable.

\section{Funding}

No funding was obtained for this study. (For all authors).

\section{Availability of data and materials}

All the data regarding the findings are available within the manuscript.

\section{Source(s) of support}

NIL

\section{Presentation at a meeting}

$\mathrm{NIL}$

\section{Authors' contributions}

TS carried out concepts \& design, literature search, participated in clinical study. PS carried out data acquisition, data analysis \& manuscript preparation. PG participated in the clinical study \& manuscript review. MP carried out concepts \& design, literature search. KK carried out data acquisition \& literature search. All the authors have read \& approved the final manuscript.

\section{Authors' information}

Dr. T Santosh-Fellow Cytopathology,Department of Pathology, Seth GSMC \& KEMH,Mumbai; Dt Pragati Sathe-Associate Professor, Department of Pathology, Seth GSMC \& KEMH,Mumbai; Dr. Prachi Gholap- Ex-Assistant Professor,Department of Pathology, Seth GSMC \& KEMH,Mumbai; Dr. Manoj Patil- PG Student, Department of Pathology, Seth GSMC \& KEMH,Mumbai; Dr. Kanchan Kothari- Associate Professor Department of Pathology, Seth GSMC \& KEMH,Mumbai.

\section{Ethics approval and consent to participate}

Not applicable.

\section{Consent for publication}

Written informed consent was obtained from the patient for publication of this case report and any accompanying images.

\section{Competing interests}

The authors declare that they have no competing interests.

\section{Publisher's Note}

Springer Nature remains neutral with regard to jurisdictional claims in published maps and institutional affiliations.

Received: 14 August 2017 Accepted: 26 February 2018

Published online: 07 March 2018

\section{References}

1. Suresh K, Pramod KS, Malay KB. Isolated abdominal wall metastasis from renal cell carcinoma: unusual presentation. Adv Biomed Res. 2015;4:65.

2. Tunio MA, Hashmi A, Epistaxis RM. Proptosis- unusual primary manifestations of metastatic renal cell carcinoma. Pak J Med Sci. 2009; 25:1012-4.

3. Tunio MA, Hashmi A, Rafi M. Renal cell carcinoma presenting as skin and ipsilateral testicular metastasis. Isra Med J. 2009;1:79-81.

4. Syriac S, Boergert S, Ganesan SI. FNA diagnosis of cutaneous metastasis of renal cell carcinoma with initial presentation as scalp lesion. Ann Clin Cytol Pathol. 2016;2(1):10-5.

5. Mutahir AT, Altaf H, Muhammad M, Rehan M. Isolated scar-site metastasis after radical nephrectomy for localized renal cell carcinoma. Pak J Surg. 2011:27(3):229-31

6. Perna AG, Ostler DA, Ivan D, Lazar AJ, Diwan AH, Prieto VG, et al. Renal cell carcinoma marker (RCC-ma) is specific for cutaneous metastasis of renal cell carcinoma. J Cutan Pathol. 2007;34:381-5.
7. Reymond MA, Schneider C, Kastl S, Hohenberger W, Kockerling F. The pathogenesis of port site recurrences. J Gastrointest Surg. 1998:2:406-14.

8. Fornara P, Zacharias M, Wagner S. Port-site metastases: fact or fiction? Urol Int. 2003;71:136-42.

9. Ji-Jian C, Kamran A, Zahoor F, Sheikh M. Solitary renal fossa recurrence of renal cell carcinoma after nephrectomy. Rev Urol. 2014;16(2):76-82.

\section{Submit your next manuscript to BioMed Central and we will help you at every step:}

- We accept pre-submission inquiries

- Our selector tool helps you to find the most relevant journal

- We provide round the clock customer support

- Convenient online submission

- Thorough peer review

- Inclusion in PubMed and all major indexing services

- Maximum visibility for your research

Submit your manuscript at www.biomedcentral.com/submit 